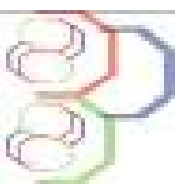

Journal of Applied Biosciences 109: 10594-10608

\title{
Garcinia lucida Vesque (Clusiaceae): from traditional uses to pharmacopeic monograph for an emerging local plant-based drug development
}

\author{
Nicole Marie GUEDJE ${ }^{\left(1^{*}\right)}$, Fulbert TADJOUTEU(2), Jean Michel ONANA(2,3), Emmanuel NNANGA NGA(4) \\ Ousseynou NDOYE (5) \\ ${ }^{1}$ Department of Pharmacognosy and Pharmaceutical Chemistry, Faculty of Medicine and Biomedical Sciences, \\ University of Yaoundé 1; manigue@hotmail.com ; +237 676075355 \\ ${ }^{2}$ National Herbarium of Cameroon, Institute of Agricutulral Research for Development (IRAD); PO Box 1601 Yaoundé \\ Cameroon \\ 3 Department of Plant Sciences, Faculty of Sciences, University of Yaoundé I. PO Box 812 Yaoundé, Cameroon \\ 4 Département de Pharmacie Galénique et Législation Pharmaceutique", Faculty of Medicine and Biomedical Sciences, \\ University of Yaoundé 1 / Institute of Medical Research and Medicinal Plants Studies P.O Box 6163 Yaoundé, Cameroon \\ ${ }^{5}$ FAO-NWFP- Food and Agriculture Organization of the United Nations (FAO), PO Box 281 Yaoundé, Cameroon \\ * Corresponding author E-mail: manigue@hotmail.com, Phone: + 237676075355
}

Original submitted in on 20th October 2016. Published online at www.m.elewa.orgon $31^{\text {st }}$ January 2017 http://dx.doi.org/10.4314/jab.v109i1.4

\begin{abstract}
Objectives: This paper seeks to assess information on the identity, traditional uses, safety and efficacy of Garcinia lucida Vesque (Essok in Boulou and Ewondo local language), in order to highlight it potential as species to be registered in medicinal plant list and formularies needed for the development of monographs leading to local production of phytomedicines.

Methodology and Results: Ethnobotanical survey was carried in the Bipindi-Akom II region (South Cameroon) with the help of interviews based on standardised questionnaires addressed to key-informants. Bark and seeds were the major parts used, highly appreciated due to its properties in preventing consumers from poison, diarrhoea and headaches. The most important therapeutic indications were additive to palm wine, antidote to poisoning, gastritis and snake bite. Other uses in treating included gynaecological pains and infections, sexual diseases and cancers. The bark was also believed by local people to act on the stability of chemical antibiotic drugs in pharmacy, while leaves were used as insect repellent against mosquitoes and cockroaches.

Conclusions and application of findings: As an additive in palm wine processing, poisoning antidote, aphrodisiac and medicines, bark and seeds are widely used in the Bipindi-Lolodorf-Akom II area, in the Centre and South regions of Cameroon, in Gabon and Equatorial Guinea, in Central Africa and West Africa. This similarity of use across many regions is considered as important biological activity marker tools guiding plant parts or species selection in drug discovery and development using ethnopharmacological approach. Through the ethnobotanical and biological tests, assessed, accurate information is provided to substantiate safety and efficacy of G. lucida and to satisfy the requirements of official compendia such as pharmacopoeia. Further studies are needed to understand the effects of bark and seeds as additive to palm wine, as well as the interaction between bark and chemical antibiotic drugs.

Keywords: Garcinia lucida, traditional uses, medicinal plant list, monograph, pharmacopoeia, phytomedicine production.
\end{abstract}




\section{INTRODUCTION}

Health systems around the world are experiencing increased levels of chronic illness and for millions of people in developing countries, herbal medicines, traditional treatments, and traditional practitioners are the main source of health care, and sometimes the only source of care (WHO, 2013). The affordability of most traditional medicines makes them more attractive at a time of soaring health-care costs and nearly universal austerity. According to Cordell (2011), it is the obligation of most of these countries to weigh the public health and economic issues of whether it will be more effective to develop local resources for the production of selected synthetic medicinal agents, to rely on imported drugs, or to establish research and possibly discovery programs, based on indigenous resources, to explore traditional medicines as health care resources. Moreover, the global resurgence of interest in herbal medicines has created a large market for plant-derived remedies that developing countries could exploit to their advantage, provided they could be produced with acceptable quality and safety specifications (Kasilo et al., 2010). To provide phytomedicines with these quality and safety specifications, a standardized mode of production, which meets modern pharmaceutical manufacturing standards, must be developed. Indeed, the development of such plant factories requires approval by the government of the respective developing country states, the existence of institutional and legal frameworks, as well as that of evidence-based information on the safety, efficacy and quality assurance of plant species or products of widely used medicinal plants according to WHO guidelines (2004a, b). Within the WHO African Region, progress have been made in policy development and country regulatory frameworks, including various instruments such as the code of ethics and the legal framework for traditional practitioners (WHO, 2011a; 2013). However, in most of these African countries, the herbal medicine consumption and market are poorly developed and regulated, and herbal products are often neither registered nor controlled. Only twelve countries issued marketing authorizations for traditional or phytomedicines, ranging from three products in
Cameroon and Congo to over 1000 in Mali, Ghana and Nigeria (WHO, 2005; 2013). To obtain registration or marketing authorization, a dossier of information on the remedy's safety and efficacy must be submitted to the national regulatory authorities. Depending on the particular country and existing legislation, herbal products are usually regulated as drugs or as "dietary supplement". To be registered these products need to be tested to prove their safety and clinical efficacy. However, few programs have been established to study the safety and efficacy of herbal medicines as proposed by the WHO Guidelines for the assessment of herbal medicines through clinical trials (Calixto, 2000; WHO, 2007; 2011b). Fortunately, the requirements for the dossier within the WHO African Region vary according to the four categories distinguished by the classification of traditional medicines (OAPI/OMS, 2004). Most improved traditional medicines are of category 1 or 2 , made of crude traditional preparations, for which clinical trials are not an absolute requirement, but rather that evidence of traditional use, according to WHO guidelines (1998; 2004a,b; 2007; 2011b). Indeed, the general tendency in the processes of regulation and registration is to combine scientific studies and traditional knowledge well documented in monographs which are important tools needed to establish official compendia and appropriate guidelines for drug registration and regulation (Calixto, 2000; Wilcox et al., 2012; WHO, 2007; $2011 b ; 2013)$. Unfortunately, very few or no countries or jurisdictions in the region have reported promoting or establishing these official compendia such as pharmacopoeias, formularies or legislative documents. Therefore, in order to effectively implement the "WHO Strategic plan for local production of traditional medicines" and ensure that traditional medicines of acceptable quality could be made available, pharmacopoeias need to be elaborated or enriched, at the national or regional levels such as the volume 1 of the African pharmacopoeia (OAU, 1985). The development of monographs on selected medicinal plants, as well as the establishment of formularies or medicinal plant list is few of the important prerequisites to this 
achievement. According to WHO (2010), monographs are valuable tools serving as source of information for regulation or registration system for medicinal plants or herbal medicines as therapeutic agents or active ingredients in the country of production. As part of efforts to the effective implementation of a local production of

\section{MATERIALS AND METHODS}

Field surveying to assess the traditional uses and the botanical characteristics of $\mathrm{G}$. lucida species was carried in the Bipindi -Lolodorf - Akom II region (South Cameroon). The research was carried out in and around two G. lucida collection sites, named Minwo'o and Akok (Fig. 1). The selected villages were Meka'a II, Nyangong and Mefak located near the Nyangong site (2856.040N, 10849.620E), and Ebom and Nkouékouk, near the site of Minwo'o (3806.040N, 10846.280E). The fieldwork included ethnobotanical survey and literature search. phytomedicines across Africa, this paper seeks to assess information on the identity, uses, safety and efficacy of Garcinia lucida Vesque, in order to highlight it potential as medicinal species to be registered in medicinal plant list or formularies needed for the development of monographs and establishment of official pharmacopoeia.

Information on the utilisation and traditional processing of G. lucida bark and seeds was collected with the help of interviews with key-informants based on questionnaires. In total, twenty key-informants (4 women, 8 young men and 8 elderly men) were selected, regarding of their past or present activities related to the exploitation of bark and seeds for additive to palm wine production and for medicinal uses. In addition, a total of 35 bark gatherers and/or traders (8 women and 27 men) provided information by filling in standardised questionnaires.

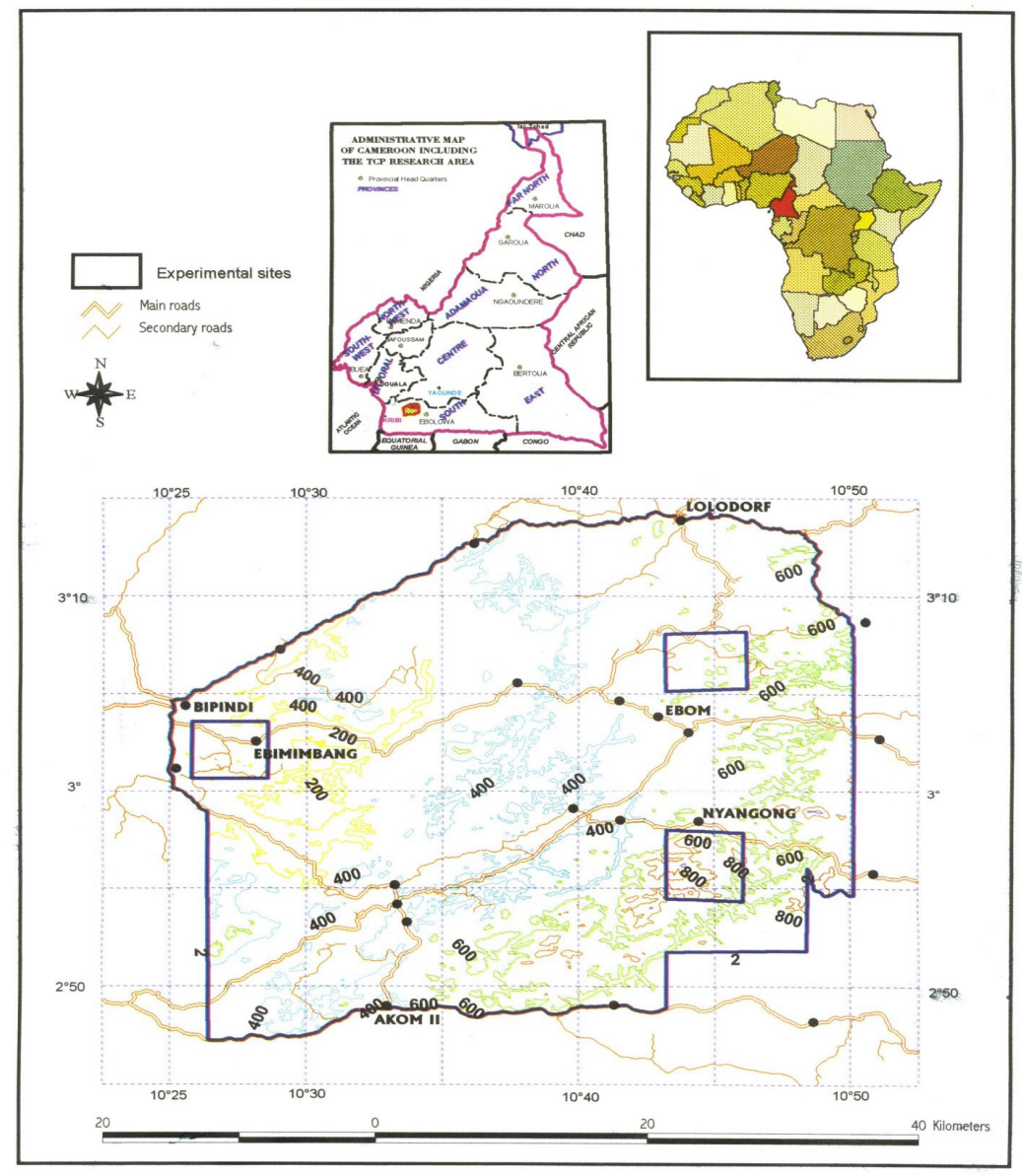

Fig. 1: Location of the Bipindi - Akom II - Lolodorf region in Cameroon 
The identification of the species was confirmed with the help of $\mathrm{Dr}$ Xander (botanist at the Herbarium of Wageningen) and voucher specimens (WAG0021844) were selected and kept at the National Herbarium of Cameroon and at the Wageningen Herbarium (Fig. 2A). The therapeutic judgements were made based on specific disease, symptom or physiological effect, grouped according to the classification proposed by the World Health Organisation (WHO) and adapted by the Organisation of the African Unity (OAU) for the

\section{RESULTS}

Botanical characteristics and distribution: G. lucida species is a small understory dioecious tree, standing sometimes on stilt roots, reaching $25-30 \mathrm{~cm}$ in diameter at breast height (dbh) and 12-15 $\mathrm{m}$ in height. Trees are of variable aspect, well-branched (Fig. 2B, 2C) and evergreen. The stem exhibits yellow and resinous exudates after the dark brown bark is cut or removed. The underside of the lanceolated leaf is of a shining golden colour. The buds are green and the flowers white (Fig. $2 \mathrm{C}$ ). The green fruits (Fig. 2D), classified as a berry, are medium-size $(13 \mathrm{~cm} \times 11 \mathrm{~cm})$, ellipsoidal or globular in form and green to green-golden in colour, and contain 1 to 3 , sometimes 4 seeds, wrapped with a thin and white
Cameroonian traditional pharmacopoeia (Adjanohoun et al., 1994; 1996). The importance of each specific disease, symptom or physiological effect was evaluated based on the number of citations made by the informants. A literature review was performed via electronic search (using PubMed, SciFinderScholar, TPL (www.the plantlist.org), Google Scholar, Bing and Web of Science). The search words were Garcinia lucida coupled with biological activity, as well as isolated compounds. These data were compiled on a excel sheet and analysed.

yellowish pulp. Seeds are medium-size $(4 \mathrm{~cm} \times 3 \mathrm{~cm} \times 2$ $\mathrm{cm}$ to $8 \mathrm{~cm} \times 6 \mathrm{~cm} \times 4 \mathrm{~cm}$ ), reddish-purple in colour and of semi-ellipsoidal form (Fig. 2E). When ripe, these seeds drop from the fruit or with the fruit on the ground beneath the parent tree. The natural habitat of G. lucida is the Atlantic "primary" humid forests. The species is usually found in hilly moist forests sides, up to $600-800 \mathrm{~m}$ above sea level, with some hills or mountains exceeding $1400 \mathrm{~m}$, with a yearly rainfall of about $2000 \mathrm{~mm}$, and with an average annual temperature of around $25^{\circ} \mathrm{C}$. G. lucida tree grows in high-density stands covering few hectares with an abundance varying from 348 young matures ( 5 $10 \mathrm{~cm} \mathrm{dbh}$ ) to 5 large trees (> $20 \mathrm{~cm} \mathrm{dbh}$ ) per hectare. 


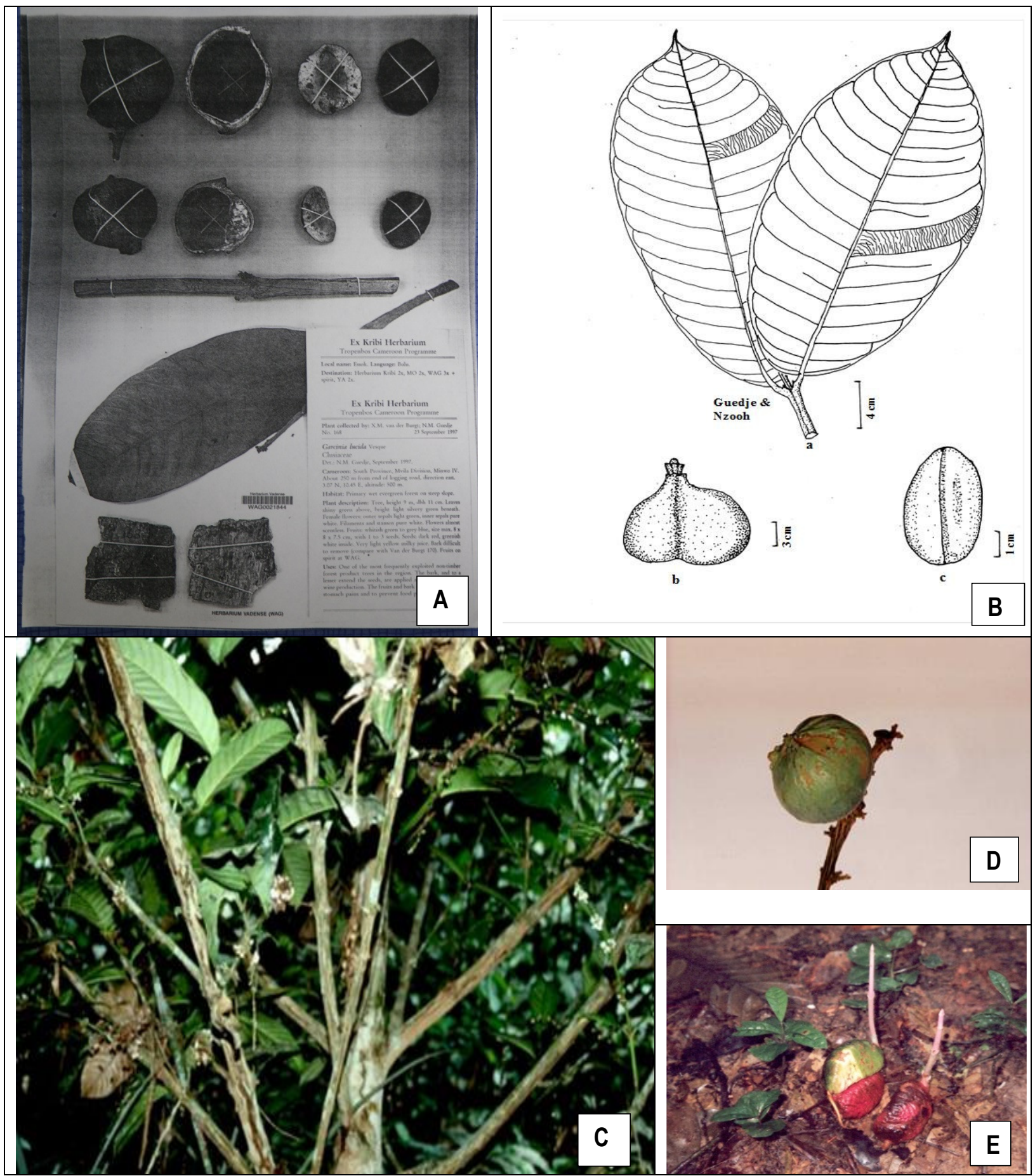

Fig. 2: Garcinia lucida Vesque (Clusiaceae) photographs selected for compendia. $A=$ voucher specimens kept at the Wageningen Herbarium, $B=$ freehand drawing of leaves, fruit and seed, $C=$ Flowering branches, $D=$ green fruit, $E=$ purple seeds.

Traditional uses: G. lucida species is widely used in the Bipindi-Lolodorf-Akom II region for its medicinal properties and physiological effects. Table 1 summarises the different therapeutic indications of $G$. Iucida, classified by physiological effect, diseases or symptom according to systems. 

pharmacopeic monograph for an emerging local plant-based drug development

Table 1: Therapeutic indications of G. lucida in the Bipindi-Lolodorf-Akom II area, classified by specific disease, symptom or physiological effect according to systems.

\begin{tabular}{|c|c|c|c|}
\hline $\begin{array}{l}\text { Effects, diseases and } \\
\text { condition Groups }\end{array}$ & Effects, diseases or symptoms & $\begin{array}{l}\text { Plant parts } \\
\text { used }\end{array}$ & $\begin{array}{c}\text { Number of } \\
\text { Citation }\end{array}$ \\
\hline \multirow{12}{*}{ Digestive system } & Diarrhoea (A09) & Bark & 7 \\
\hline & \multirow{2}{*}{$\begin{array}{l}\text { Abdominal distending or Flatulence (R14); } \\
\text { Indigestion or Constipation (K59.0) }\end{array}$} & Seeds & 5 \\
\hline & & Roots & 2 \\
\hline & \multirow[t]{2}{*}{ Gastralgia (R10.1) } & Bark & 5 \\
\hline & & Seeds & 3 \\
\hline & \multirow[t]{2}{*}{ Abdominal pains (R10.4) } & Bark & 5 \\
\hline & & Seeds & 3 \\
\hline & \multirow[t]{3}{*}{ Gastritis (K29.7), gastric ulcer } & Seeds & 20 \\
\hline & & Bark & 18 \\
\hline & & Fruits & 3 \\
\hline & Peptic ulcer & Bark & 2 \\
\hline & & Seeds & 2 \\
\hline Directions for medico-magic use & against evil spirits; Chase away ghosts & Leaves & 6 \\
\hline $\begin{array}{l}\text { Effects on parasite or } \\
\text { pathogenic organisms }\end{array}$ & $\begin{array}{l}\text { Insect repellent, merely against mosquitoes } \\
\text { and cockroaches }\end{array}$ & Leaves & 4 \\
\hline \multirow{2}{*}{$\begin{array}{l}\text { Effects on reproductive system, } \\
\text { in relation with glandular } \\
\text { systems }\end{array}$} & \multirow[t]{2}{*}{ Aphrodisiac / stimulant } & Fruits & 5 \\
\hline & & Seeds & 5 \\
\hline $\begin{array}{l}\text { Female genital system: } \\
\text { obstetrics and gynaecology }\end{array}$ & $\begin{array}{c}\text { Gynaecological pains and infections } \\
\text { (unspecified) }\end{array}$ & Seeds & 7 \\
\hline \multirow[t]{3}{*}{ Infectious diseases } & Sexual transmittable diseases (unspecified) & Seeds & 2 \\
\hline & \multirow[t]{2}{*}{ Measles (B05.9) } & Seeds & 5 \\
\hline & & Bark & 5 \\
\hline \multirow[t]{3}{*}{ Miscellaneous or sundry usages } & \multirow[t]{3}{*}{ Additive } & Bark & 35 \\
\hline & & Root bark & 2 \\
\hline & & Seeds & 25 \\
\hline \multirow{8}{*}{$\begin{array}{l}\text { Specific diseases and } \\
\text { conditions (miscellaneous) }\end{array}$} & \multirow[t]{3}{*}{ Cancer (unspecified) (D48.9) } & Bark & 2 \\
\hline & & Seeds & 2 \\
\hline & & Roots & 2 \\
\hline & \multirow[t]{4}{*}{ Antidote / Poisoning (T65.9) } & Bark & 30 \\
\hline & & Fruits & 4 \\
\hline & & Seeds & 30 \\
\hline & & Roots & 2 \\
\hline & Snake bite (T63.0) & Seeds & 25 \\
\hline \multirow[t]{2}{*}{ Specific symptoms } & Generalised pain (R52.9) & Bark & 2 \\
\hline & Total number of citations & & 275 \\
\hline
\end{tabular}

Almost every part of $\mathrm{G}$. lucida trees is useful in traditional medicine, ranging from the seeds $(49 \%$ of citations or indications) to it root-bark (1\%). However, seeds and bark are the parts mostly used for the different effects, diseases and conditions (Fig. 3). These seeds and bark, dried or fresh, are often used to treat various diseases, including diarrhoea, abdominal pains, flatulence, constipation, gastralgia, gastritis or stomach ulcers, and mostly, snakebites and food poisoning. The bark and seeds are also used in the treatment of gynaecological pains and infections, sexual transmittable diseases, generalised pain and cancers. The use of leaves against evil spirits or to chase away ghosts and as insect repellent, merely against mosquitoes and cockroaches, was mentioned only by elderly key-informants. Furthermore, local people in the Bipindi-Akom II region 


\section{Guedje et al., J. Appl. Biosci. 2017 Garcinia lucida Vesque (Clusiaceae): from traditional uses to}

pharmacopeic monograph for an emerging local plant-based drug development

strongly advice people against to enter in a pharmacy

deactivate pharmaceutical antibiotics.

with a piece of $G$. lucida bark, which is believe to

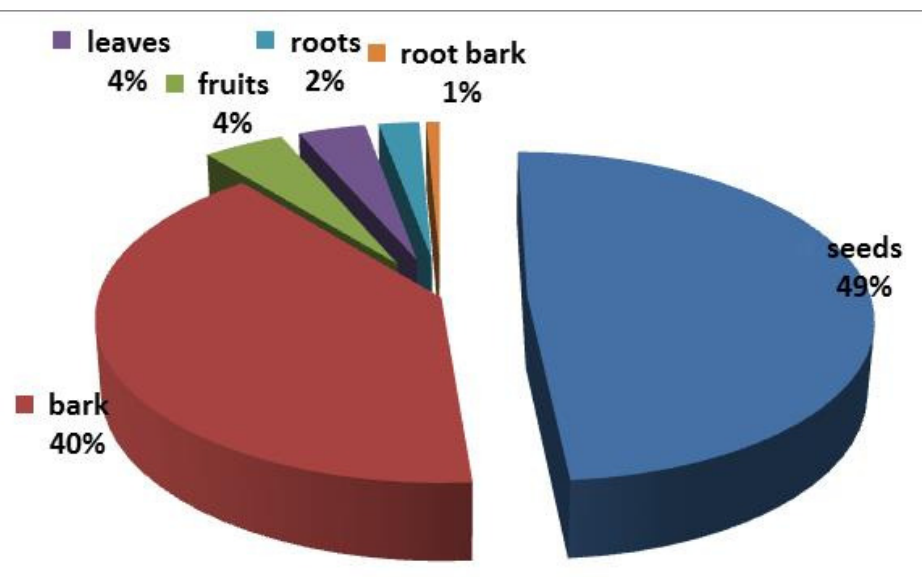

Fig. 3: Relative importance of Garcinia lucida plant parts used in the Bipindi-Lolodorf-Akom II region.

G. lucida bark, as an additive or flavour in palm wine production and in palm wine distilled to obtain traditional liquor named "Mkpwet" (fermented wine) and "Odontol" (distilled wine) is widely used in the Bipindi-Lolodorf-Akom II area. The seeds and the bark of the root are sometimes used for this purpose; however, the bark is the most popular plant part used. During the survey, almost all the informants indicated that $G$. lucida bark was widely and highly appreciated due to its properties preventing palm wine consumers from diarrhoea, headaches occurring after getting drunk, and the most important, from wine poison.
Relative importance of therapeutic indications: The relative importance of the different physiological effects, diseases and symptoms recorded for $G$. lucida species is illustrated in Fig. $4 a$, with additive (24\% of the citations), antidote to poisoning (22\%), gastritis $(15 \%)$ and Snakebite $(9 \%)$ as the most important therapeutic indications. Specific diseases and conditions (33\%), digestive system (27\%) and miscellaneous usages (24\%) are in this order, the most important therapeutic indication groups treated with G. lucida plant parts (Fig. 4b). 


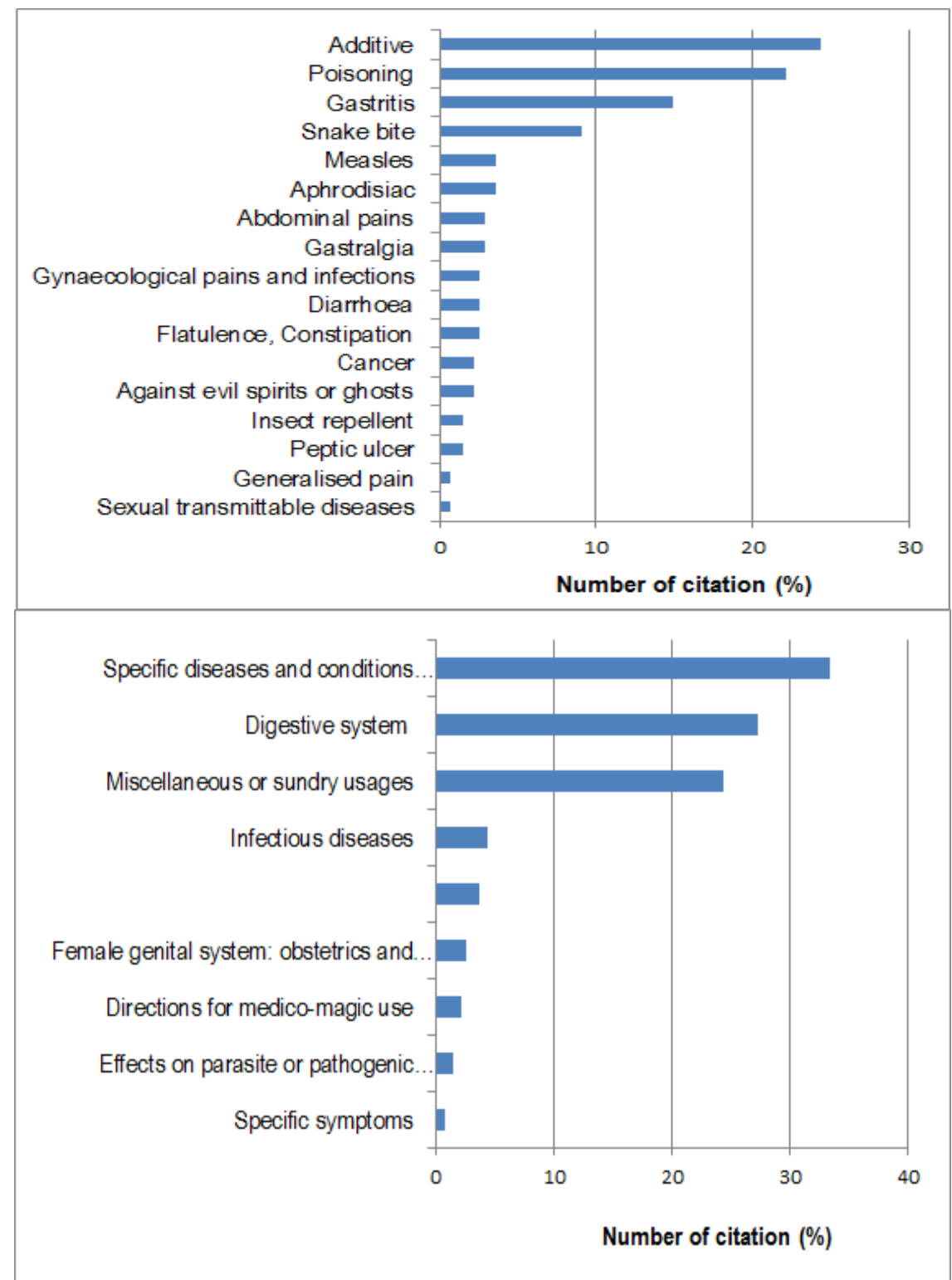

Fig. 4: Relative importance of therapeutic indications of G. lucida in the Bipindi-Lolodorf-Akom II area, classified by physiological effect, diseases or symptom according to systems. A = Relative importance of physiological effects, diseases or symptoms recorded, $B=$ relative importance of therapeutic indication groups treated with different plant parts.

\section{DISCUSSION}

Definition and taxonomy of Garcinia lucida Vesque (Clusiaceae): According to WHO (2003; 2010), some reported adverse events following the use of certain herbal medicines have been associated with a variety of possible explanations, including the inadvertent use of the wrong plant species. Therefore, as stated by Brigham et al. (2004) and WHO (2003; 2004b; 2007), an accurate and adequately identification of medicinal plant species, with voucher specimens from the collection site, represents one of the key elements of the development of pharmaceutical industries based on high quality and safety specifications; as it allow each batch of goods to be traced back to the area where it was collected or produced. The present paper has been supplemented with $G$. lucida specimen voucher, freehand drawing and typical photographs (Fig. 2), in order to facilitate the species identification and to avoid confusion with other species at it has been noted during literature search where, some works assessing biological activity or phytochemical components have been published with 


\section{Guedje et al., J. Appl. Biosci. 2017 Garcinia lucida Vesque (Clusiaceae): from traditional uses to pharmacopeic monograph for an emerging local plant-based drug development}

pictures not corresponding to those of $G$. lucida species accurately identified by trained botanists. According to the Linear Angiosperm Phylogeny Group III (LAPG III), G. lucida Vesque is scientifically classified as follows (Haston et al. 2009): Kingdom: Plantae; Division: Magnoliophyta; Class: Magnoliids or Magnoliopsida; SubClass: "Eudicots" or "Eudicotyledons"; Order: Malpighiales Juss. ex Bercht. \& J.Presl (1820) or Theales; Family: Clusiaceae Lindl. (1836) or Guttiferae; Genus: Garcinia. Therefore, in each pharmacopoeia summary, the definition section providing the Latin binomial pharmacopoeia name is the most important criterion in quality assurance, according to WHO (2010). The detailed botanical description is also intended for quality assurance at the stages of production and collection, whereas the detailed description of the plant part used or drug material is for the same purpose at the manufacturing and commerce stages. The geographical distribution information is included to provide additional quality assurance information. According to Bamps (1970), the geographical distribution of $G$. lucida is limited to parts of Cameroon, Equatorial Guinea and Gabon; however, the species was indicated to be used as additive to palm wine in Central and West Africa by Irvine (1961), Bouquet (1969) Bouquet and Debray (1974). In Cameroon, Vivien and Faure (1996) indicated that the species can be found in the following regions: Yaoundé, Akom II, Akonolinga, Bijoka, Bipindi, Ebolowa, Edip (Kupe-Muanenguba), Korup National Park, Lolodorf, Matomb, Mbam Minkom, Mbanga (81 Km Kribi-Ebolowa road), Mfou, Ndikinimeki and Nta Ali (25km SE Mamfe). Convergence or similarity of use: The importance of $G$. lucida is derived from its therapeutic indications. As an additive or flavour (Miscellaneous usages) in palm wine production and distilled, bark and seeds are widely used in the Bipindi-Lolodorf-Akom II area, in the Centre and South regions of Cameroon (Noumi, 1984; Ndoye, 1995; van Dijk, 1999; Ndoye et al., 2001), Gabon and Equatorial Guinea (Ndoye et al., 1999; 2000; Sunderland and Obama, 1999), Central Africa and West Africa (Irvine, 1961; Bouquet, 1969; Bouquet and Debray, 1974). Noumi (1984) has listed many plant products used in the production of palm wine in Cameroon. In the Bipindi Akom II region Garcinia kola, Phyllanthus muellerianus, Sacoglottis gabonensis, Alstonia boonei, Pentaclethra macrophylla, Piper guineense, Ceiba pentandra and Carapa procera were mentioned also to be used in palm wine production (van Dijk 1999). Informants indicated that the bark of all those species was rarely used, although it was frequently used in the past. However, G. lucida bark was widely and mostly appreciated due to its properties against wine poison, diarrhoea and headaches. As medicine, in rural communities, where villagers have hardly access to health centres, the use of bark and seeds to treat diarrhoea, abdominal pains, flatulence, constipation, gastralgia, gastritis or stomach ulcers (digestive system) was also reported throughout the Centre and South regions of Cameroon (Nyemba et al., 1990; Kuete et al., 2011), at Douala in the Littoral region (Dibong et al., 2013; Ngene et al. 2015) and at Bangangte in the West region (Noumi \& Dibakto, 2000). The bark and seeds enjoy a folk reputation as antidote to poisoning and snake bites (Specific diseases and conditions miscellaneous), and as aphrodisiac or stimulant (Effects on reproductive system, in relation with glandular systems) not only in the Bipindi-Akom II region, but also in Douala (Dibong et al., 2013; Ngene et al., 2015), Yaoundé, Kribi (Adjanohoun et al., 1996), and throughout Cameroon, especially in the South and Central regions (Kamanyi et al., 1990; Nyemba et al. 1990; Vivien \& Faure, 1996; Ndoye et al. 1999; Sunderland et al., 1999; Kuete et al., 2011). The use of leaves against evil spirits or to chase away ghosts (Directions for medico-magic use) and as insect repellent (Physiological effects on parasite or pathogenic organisms), mentioned by elderly key-informants of the Bipindi-Akom II region, suggests that this type of ethnobotanical use was applied in the past. Such usage, not yet mentioned in the literature, suggests that further studies are needed to fully understand its insecticide or repellent mechanisms and how it could best be utilized for this purpose. As additive, poisoning antidote, aphrodisiac and medicines for therapeutic indication groups (such as digestive system, specific diseases and conditions, specific symptoms), a remarkable convergence or similarity of bark and seed uses is observed between Bipindi-Lolodorf-Akom II region and others regions throughout Cameroon (Akak, Bagangté, Binyenyale, Douala, Yaoundé, Kribi, the Center and South regions of Cameroon in general), Central and West Africa (Gabon, Equatorial Guinea, Congo, Ivory Coast, Ghana, Nigeria). From the perspectives of drug discovery and development using ethnopharmacological approach or method, the notion of convergence of use, considered as biological activity markers according to Fleurentin et al. (2011), is a key concept to validate the source of information (Edwards et al., 2005; Heinrich et al., 2009) and therefore constituted one of the most useful approaches guiding the selection of plant species and/or plant parts for further pharmacological studies, ethnopharmacological experimental or clinical investigations. The ethnopharmacological method is particularly useful when 


\section{Guedje et al., J. Appl. Biosci. 2017 Garcinia lucida Vesque (Clusiaceae): from traditional uses to pharmacopeic monograph for an emerging local plant-based drug development}

searching for compounds, which are effective in treating specific health conditions. This approach may be strengthened by comparing the plants used by different ethnic groups who live in the same region. It may be that species used in a similar way by a majority of local peoples are more likely to contain a physiologically active substance than species, which are used by only one ethnic group or in a single community (Martin, 1995). An illustrative example is the garden spurge, for which a study highlighting the importance of certain taxa to treat skin conditions in Brisbane, Australia allowed the identification and development of the second most commonly mentioned species, Euphorbia peplus, as an interesting lead, now in Phase II clinical trials (AndradeCetto \& Heinrich, 2011).

Constituents and biological activities warranting traditional uses: From the literature survey, G. lucida was found to have several compounds isolated from different plant parts (Annex 1). Chemical tests carried out have permit to isolate from seeds, leaves and bark of $G$. lucida, bioflavonoids, anthocyanins, saponins, carbohydrates, triterpenes and derivatives of cycloartane (Etounou, 1991). Furthermore, phytochemical studies conducted by Nyemba et al. (1990) led to the isolation from the bark of three cycloartanes: 30-hydroxycycloartenol, 31-norcycloartenol and 24, 25-epoxy-31-norcycloartenol (mixture of epimers). Cycloartenol is known as an intermediate in the biosynthesis of phytosterols. Investigations conducted by Fotié et al. (2007) have led to the isolation of trypanocidal and antileishmanial dihydrochelerythrine derivatives in addition with five known others products isolated: stigmasterol, betulenic acid, D-glucopyranoside of sitosterol, sesamin and trans-fagaramide. According to Momo et al. (2011), Dichloromethane sub-fraction from the methanol crude extract of the stem bark of $G$. lucida afforded eleven compounds namely putranjivic acid 1 , methyl putranjivate 3 , their intermediary lactone 2 , friedeline 4, cycloartenol 5, 1,2-dihydroxy- xanthone $\mathbf{6}$, 1-hydroxy-2-methoxyxanthone 7, betulinic acid 8, oleanolic acid $9, \beta$-sitosterol 10 and stigmasterol 11. Most of the isolated metabolites from the G. lucida are alkaloids, flavonoids, phenols and polyphenols, tannins, anthraquinones, steroids, saponins, glycosides (Lacmata et al., 2012; Ntie-Kang et al., 2013; Djacbou et al., 2014). At the Medical Institute of Medicinal Plants of Cameroon (IMPM, 1987), cycloartane derivatives and triterpene pentacycliane, anti-inflammatory and anti-acids active component were isolated from the leaves and bark of $G$. lucida. Antibacterial activity was also detected in extracts of bark and seeds of G. lucida at the Centre for the Study of Medicinal Plants of Cameroon (CEPM) of the IMPM institute. The presence of these anti-inflammatory and anti-acid compounds might explain and validate its uses in traditional medicine against gastrointestinal disorders (abdominal pains, gastralgia, gastric ulcer, peptic ulcer, diarrhoea, constipation) in the Bipindi-Lolodorf-Akom II region and other areas. An inhibitory effect of extracts of G. lucida seeds on curare have been proved by Kamanyi et al. (1990). Curare, administered by intra-péritonienne injection has no effect on mice that have ingested seven hours earlier, G. lucida seed extracts. According to these authors, the action of these extracts seems to be more effective in prophylactic action than in curative treatment. The results of this work, which also shown that these extracts were non-toxic, justify why local populations preferentially use the bark of $G$. lucida to produce and spread their palm wine and think that they are guard against possible poisoning. These probably also explain its reported aphrodisiac properties. In their efforts to find new bioactive $\beta$-lactamase inhibitors, Gangoué-Piéboji et al. $(2007 ; 2009)$ investigated 16 Cameroonian plants and found that, extracts from $G$. lucida, together with other species, presented interesting in vitro $\beta$-lactamase inhibition. The isolation and the structural elucidation of the active constituents of $G$. lucida could provide useful leads in the development of $\beta$-lactamase inhibitors. Furthermore, the extracts of $G$. lucida leaves have demonstrated broad spectrum activity against all tested Gram-negative bacilli with inhibition zones in the range of 9-23 mm, good activity on non-fermenter Gram-negative bacilli ( $P$. aeruginosa and $A$. baumannii), high potency on beta-lactam-resistant Gram-positive cocci (Enterococcus sp P054 and S. aureus U127). Moreover, G. lucida extracts showed good antifungal activities on filamentous fungi. The antibacterial activities of twelve methanol extracts of medicinal plants were evaluated using broth microdilution by Lacmata et al. (2012). The results of their test showed that extracts from $\mathrm{G}$. Iucida with the minimal inhibitory concentrations (MIC) varying from 128 to 512 $\mu \mathrm{g} / \mathrm{mL}$ were one of the most active on all the 29 studied bacteria including MDR (multi drug resistance) phenotypes. The results of this study suggested that the tested plant extracts and mostly those from Picralima nitida, G. lucida and G. kola could be used alone or in association with common antibiotics in the fight of bacterial infections involving MDR strains. These different results support the traditional antimicrobial use of this species in digestive system, gynaecological and infectious diseases. Djacbou et al. (2014) have found a high antiradical activity in $\mathrm{G}$. lucida bark and fruit extracts, measured by the ability to scavenge DPPH free radicals. 
The extracts have potent nitric oxide scavenging activity. The species can be useful for the management of diseases in which radical nitrite is directly involved. Extracts of Acalypha racemosa, G. lucida and Hymenocardia lyrata have higher total phenol content and antioxidant activity. Concerning the safety of the plant, people in the Bipindi-Lolodorf-Akom II region agreed on the non-toxicity of $G$. lucida seeds and bark since many years of uses. No side or adverse effects, as well as no contraindications were reported. Gangou'e-Pi'eboji et al. (2007) have demonstrated that G. lucida has little toxicity to vero cells and the host cells; they concluded that this species could be source of compounds, which might be useful in managing beta-lactam resistant bacteria and extended spectrum beta-lactamase-producing enterobacteria. Kamanyi et al. (1990) have also highlighted that $G$. lucida seed extracts were non-toxic; indicating therefore that $G$. lucida is safe consumed with or without other foods. These various phytochemical and biological tests show that many active compounds are found in G. lucida bark, seeds and leaves, with bioactivities such as intermediate phytosterols biosynthesis intermediary, antibacterial, antimicrobial, anti-inflammatories, antacids, antiradical, curare antidote or inhibitory effect, $\beta$-lactamase inhibition, antibacterial involving MDR strains. This thereby conferring to the species, a great therapeutic value and potential in drug innovation and development, as well as strengthening the link between the traditional knowledge and modern science.

Traditional uses and pharmacopeic monographs: As stated by Wilcox et al. (2012), one of the most important advantages of "improved phytomedicines" is that they can be developed much faster and more inexpensively than new modern drugs. This is because their use, preparation and safety are already understood in traditional knowledge systems, and so preclinical development can be greatly accelerated. According to WHO (1998) guidelines, no requirement for preclinical toxicity testing, but rather that evidence of traditional use or recent clinical experience is sufficient. In addition,

\section{ACKNOWLEDGMENTS}

The authors gratefully acknowledge the financial support of the Ministry of Higher Education in Cameroon. The authors are also grateful to the inhabitants of BipindiLolodorf-Akom II region who helped to conduct the survey and provided useful information. Dr Xander van der Burgt is acknowledged for providing the photograph of the voucher specimens kept at the Herbarium of
WHO (2007) specifications for pharmaceutical preparations highlight the fact that if the product has been traditionally used without demonstrated harm, no specific restrictive regulatory action should be undertaken unless new evidence demands a revised risk-benefit assessment. Therefore, the remarkable convergence of bark and seed usages observed between BipindiLolodorf-Akom II region and others regions throughout Cameroon, Central and West Africa highlights the potential of $G$. lucida to be compiled or registered in the list of medicinal plants that helped the establishment of national specifications for the most widely used medicinal species and simple preparations. Furthermore, through the ethnobotanical and biological tests analyzed in this paper, accurate and sufficient scientific information and data have been provided to substantiate safety and efficacy of $G$. lucida species and to satisfy the requirements of the various sections in the development process of monographs and consequently the establishment of official compendia such as pharmacopoeia, formularies or legislative documents. As complete monographs of medicinal plant species listed in official compendia are one of the important elements of the brochure or dossier for requesting a marketing authorization for phytomedicine, this report has direct bearing on attempts to facilitate the establishment of quality specifications and standards by national drug regulatory authorities, as well as quality assurance and control measures leading to massive phytomedicine production across Africa, meeting modern pharmaceutical manufacturing standards. Further studies are needed to fully understand the physiological effects of bark and seeds as additive to palm wine, as well as the interaction between the bark and the stability of chemical antibiotic drugs in pharmacy. Furthermore, no pharmacological evidence was found to support the aphrodisiac or stimulant properties, as well as the antidote to snake bite and several others utilizations, indicating that $G$. lucida is still a good candidate for further biological research leading to drug discovery and innovation.

Wageningen. It is author's sincere hope that information of this paper will be useful to pharmacist students and to all who are expected to valorise the vast resources of African medicinal plants and care about health in African regions. We also thank the anonymous reviewers for their precious comments. 


\section{REFERENCES}

Adjanohoun E, Cusset G, Issa Lo, Keita A, Lebras M, Lejoly J, 1994. Banque de données de médecine traditionnelle et de pharmacopée (Pharmel). Notice pour la collecte et l'entrée des

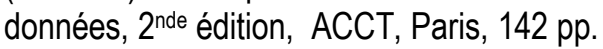

Adjanohoun E, Aboubakar N, Dramane K, Ebot ME, Ekpere JA, Enow-Orock EG, Focho D, Gbilé ZO, Kamanyi A, Kamsu Kom J, Keita A, Mbenkum T, Mbi CN, Mbiele AL, Mbome IL, Mubiru NK, Nancy WL, Nkongmeneck B-A, Satabié B, Sofowora A, Tamze V, Wirmum CK, 1996. Contribution to ethnobotanical and floristic studies in Cameroon. CSTR/OUA, $641 \mathrm{pp}$.

Andrade-Cetto $A$ and Heinrich M, 2011. From the field into the lab: useful approaches to selecting species based on local knowledge. Frontiers in Pharmacology / Frontiers in Ethnopharmacology 2 (20):1-5. doi: 10.3389/fphar.2011.0020.

Bamps P, 1970. Notes sur les Guttiferae d'Afrique tropicale. Bulletin du Jardin Botanique National de Belgique 40: 281-290.

Bouquet A and Debray M, 1974. Plantes médicinales de la Côte d'Ivoire. ORSTOM, Paris. 175 pp.

Bouquet $A, 1969$. Féticheurs et Médecines traditionnelles du Congo. ORSTOM, Paris.

Brigham T, Schröder M, Cocksedge W, 2004. Bonnes Pratiques d'identification pour l'Industrie des plantes (médicinales, aromatiques, culinaires) et des épices. "Centre for Non-timber Resources", Royal Roads Université.

Calixto JB, 2000. Efficacy, safety, quality control, marketing and regulatory guidelines for herbal medicines (phytotherapeutic agents). Brazilian Journal of Medical and Biological Research 33:179-189. ISSN 0100-879X.

Cordell GA, 2011. Sustainable Medicines and Global Health Care. Planta Medica 77(11):1129-38. doi: 10.1055/s-0030-1270731. Epub 2011.

Dibong SD, Tchatat M, Yinyang J, Mvogo Ottou PB, Ndjib RC, Mpondo Mpondo E, 2013. Valorisation des produits forestiers non-ligneux spéciaux d'origine végétale vendus dans les marchés de la ville de Douala (Cameroun). Journal of Animal \& Plant Sciences 20(1): 3067-3078.

Djacbou DS, Pieme CA, Cabral Biapa PC, Penlap Beng V, 2014. Comparison of in vitro antioxidant properties of extracts from three plants used for medical purpose in Cameroon: Acalypha racemosa, G. lucida and Hymenocardia lyrata.
Asian Pacific Journal of Tropical Biomedicine 4: S625-S632.

Edwards S, Nebel S, Heinrich M, 2005. Questionnaire surveys: methodological and epistemological problems for field-based ethnopharmacologists. Journal of Ethnopharmacology100: 30-36.

Etounou AMN, 1991. Etude phytochimique de quelques plantes médicinales du Cameroun: Garcinia lucida (Clusiacées) et Guibourtia tessmannii (Césalpiniacées). Thèse de troisième cycle, Université de Yaoundé, Cameroun. 138 pp.

Fleurentin J, Weniger B, Bourdy G, 2011. Traditions thérapeutiques et médicine de demain. Les enjeux de l'ethnopharmacologie. OUEST FRANCE, France. ISBN 9782737352546.

Fotie J, Bohle DS, Olivier M, Gomez MA, Nzimiro S, 2007. "Trypanocidal and antileishmanial dihydrochelerythrine derivatives from Garcinia lucida." Journal of Natural Products 70(10): 1650-1653.

Gangoué-Piéboji J, Baurin S, Frère J M, Ngassam $P$, Ngameni B, Azebaze A, Pegnyemb DE, Watchueng J, Goffin C, Galleni M, 2007. Screening of some medicinal plants from Cameroon for $\beta$ llactamase inhibitory activity. Phytotherapy Research 21(3): 284-287.

Gangoué-Pieboji J, Eze N, Djintchui AN, Ngameni B, Tsabang N, Pegnyemb DE, Biyiti L, Ngassam P, Koulla-Shiro S, Galleni M, 2009. The in-vitro antimicrobial activity of some medicinal plants against $\beta$-lactam-resistant bacteria. The Journal of Infection in Developing Countries 3(9): 671680.

Haston E, Richardson JE, Stevens PF, Chase MW, Harris DJ, 2009. LAPG III: a linear sequence of the families in APG III. Botanical Journal of the Linnean Society 161: 128-131.

Heinrich M, Edwards S, Moerman D, Leonti M, 2009. Ethnopharmacological field studies: A critical assessment of their conceptual basis and methods. Journal of Ethnopharmacology 124: $1-17$.

Institut de Médecine de d'Etudes des Plantes Médicinales (IMPM), 1987. Rapport d'activités scientifiques et techniques du Centre d'Etudes des Plantes Médicinales 86/87, Vol. II - 3. IMPM, Yaoundé, Cameroun.

Irvine FR, 1961. Woody Plants of Ghana. With special reference to their uses. London Oxford University Press, London. 868 pp. 


\section{Guedje et al., J. Appl. Biosci. 2017 Garcinia lucida Vesque (Clusiaceae): from traditional uses to}

pharmacopeic monograph for an emerging local plant-based drug development

Kamanyi A, Bopelet A, Sondengam BL, Kimbu FS, 1990. Preliminary phytochemical and pharmacological studies of the seeds of Garcinia lucida (Vesque). Nigerian Journal of Physiological Sciences 6(1): 62-66.

Kasilo OMJ, Kofi-Tsekpo MJ, Kofi MB, 2010. Towards sustainable local production of traditional medicines in the African Region. African Health Monitor 14 (Special issue): 80-88.

Kuete V, Krusche B, Youns M, Voukeng I, Fankam AG, Tankeo S, Efferth T, 2011. Cytotoxicity of some Cameroonian spices and selected medicinal plant extracts. Journal of Ethnopharmacology 134(3): 803-812.

Lacmata ST, Kuete V, Dzoyem JP, Tankeo SB, Teke GN, Kuiate JR, Pages JM, 2012. Antibacterial activities of selected Cameroonian plants and their synergistic effects with antibiotics against bacteria expressing MDR phenotypes. Evidence-Based Complementary and Alternative Medicine Volume 2012, Article ID 623723, 11 pages, doi:10.1155/2012/623723.

Martin GJ, 1995. Ethnobotany. A methods manual. Chapman \& Hall, London, UK, 268 pp.

Momo IJ, Kuete V, Dufat H, Michel S, Wandji J, 2011. Antimicrobial activity of the methanolic extract and compounds from the stem bark of Garcinia lucida Vesque (Clusiaceae). International Journal of Pharmacy and Pharmaceutical Sciences 3( 3): 215-217. ISSN- 0975-1491.

Ndoye O, 1995. The market of non-timber forest products in the humid forest zone of Cameroon and its borders. Structure, conduct, performance and policy implications. CIFOR, Yaoundé. $86 \mathrm{pp}$.

Ndoye O, Perez MR, Eyebe A, 1999. Non-Wood Forest Product Markets and Potential Degradation of the Forest Resource in Central Africa: the Role of research in providing a balance between welfare improvement and forest conservation. Sunderland TCH, Clark LE, Vantomme P (Editors), FAO, Rome, pp. 183-206.

Ndoye 0 , Ruiz-Perez M, Mamoun AD, Lema-Ngono D, 2000. Les effets de la crise économique et de la dévaluation sur l'utilisation des plantes médicinales au Cameroun. Implications pour la gestion durable des forêts. La gestion des forêts denses africaines aujourd'hui. Nasi R, Amsallem I, Drouineau S (Editors), CDRom, Cirad, Montpellier, France. pp. 76-81.

Ndoye O, Ruiz-Perez M, Eyebe A, 2001. NTFP markets and potential degradation of forest resources in
Cameroon: the case of Garcinia lucida. European Tropical Forest Research Network News 32: 44-45.

Ngene JP, Ngoule CC, Kidik CP, Ottou PM, Dibong SD, Mpondo EM, 2015. Importance dans la pharmacopée traditionnelle des plantes à flavonoïdes vendues dans les marchés de Douala est (Cameroun). Journal of Applied Biosciences 88(1): 8194-8210.

Noumi E, 1984. Les plantes à épices, à condiments et à aromates du Cameroun. Thèse de troisième cycle, Université de Yaoundé, Cameroun.

Noumi E and Dibakto TW, 2000. Medicinal plants used for peptic ulcer in the Bangangte region, western Cameroon. Fitoterapia 71(2000): 406-412.

Ntie-Kang F, Likowo Lifongo L, Meva'a Mbaze L, Nnange Ekwelle, Owono Owono LC, Megnassan E, Judson PN, Sippl W, Efange SMN, 2013. Cameroonian medicinal plants: a bioactivity versus ethnobotanical survey and chemotaxonomic classification. BMC Complementary and Alternative Medicine 2013, 13:147. http://www.biomedcentral.com/1472$6882 / 13 / 147$.

Nyemba AM, Ngando-Mpondo T, Connolly JD, Rycroft DS, 1990. Cycloartane derivatives from Garcinia lucida. Phytochemistry 29(3): 994-997.

Organisation of African Unity (OAU), 1985. African pharmacopoeia, Vol. 1, $1^{\text {st }}$ edition, Scientific, Technical \& Research Commission, OAU, Lagos.

Organisation Africaine de la Propriété Intellectuelle (OAPI) / Organisation Mondiale de la Santé (OMS), 2004. Référentiel pour l'harmonisation des procédures d'homologation des médicaments issus de la pharmacopée traditionnelle dans les pays membres de l'OAPI. OAPI / OMS, Bamako, 49 pp.

Sunderland TCH and Obama C, 1999. A preliminary market survey of the non-timber forest products of Equatorial Guinea. Sunderland TCH, Clark LE, Vantomme P (Editors), FAO, Rome, Italy. pp. 183-206.

van Dijk JFW, 1999. Non-timber forest products in the Bipindi-Akom II Region, Cameroon: a Socioeconomic and Ecological Assessment. Tropenbos-Cameroon Series 1, The Tropenbos Cameroon Programme, Kribi, Cameroon.

Vivien J and Faure JJ, 1996. Fruitiers sauvages d'Afrique : espèces du Cameroun. Nguila-Kerou, Carnoe, France. 
Willcox M, Sanogo R, Diakite C, Giani S, Paulsen BS, Diallo D, 2012. Improved Traditional Medicines in Mali. Journal of Alternative and Complementary Medicine 18(3): 212 -220. doi: 10.1089/acm.2011.0640 PMCID: PMC3306581.

World Health Organization (WHO), 1998. Guidelines for the Appropriate Use of Herbal Medicines. WHO Regional Office for the Western Pacific, Manila.

World Health Organization (WHO), 2003. WHO Guidelines on good agricultural and collection practices (GACP) for medicinal plants. WHO, Geneva. ISBN 9241546271.

World Health Organization (WHO), 2004a. Guidelines on registration of traditional medicines in the WHO African Region. WHO Regional Office for Africa, Brazzaville. AFR/TRM/04.01.

World Health Organization (WHO), 2004b. Guidelines on clinical study of traditional medicines in WHO African Region. WHO Regional Office for Africa, Brazzaville. AFR/TRM/04.04.

World Health Organization (WHO), 2005. National policy on traditional medicine and regulations of herbal medicines. Report of a WHO Global Survey. WHO, Geneva.

World Health Organization (WHO), 2007. WHO guidelines on good manufacturing practices (GMP) for herbal medicines. WHO, Geneva.

World Health Organization (WHO), 2010. WHO monographs on medicinal plants commonly used in the Newly Independent States (NIS). WHO, France, ISBN 9789241597722 , 452 pp.

World Health Organization (WHO), 2011a. Progress report on decade of traditional medicine in the Africa region. WHO African Region (AFRO), Brazzaville. AFR/RC61/PR/2.

World Health Organization (WHO), 2011b. Quality control methods for herbal materials (updated edition of 1998 publication). WHO, Malta, 187 pp. ISBN 9789241500739.

World Health Organization (WHO), 2013. WHO traditional medicine strategy: 2014-2023. WHO Press, Hong Kong SAR, China, 78 pp. ISBN 978924 1506090.

Annex 1. Phytochemical composition and Bioactivities of Garcinia lucida crude extract.

\begin{tabular}{|c|c|c|c|}
\hline $\begin{array}{l}\text { Plant Parts } \\
\text { studied }\end{array}$ & Components & Bioactivities of crude extract & References \\
\hline $\begin{array}{l}\text { Seeds, } \\
\text { leaves, bark }\end{array}$ & $\begin{array}{l}\text { bioflavonoids, anthocyanins, saponins, } \\
\text { carbohydrates, triterpenes and } \\
\text { derivatives of cycloartane } \\
\text { Three cycloartanes: } \\
\text { 30-hydroxycycloartenol, } \\
\text { 31-norcycloartenol and } \\
\text { 24,25-epoxy-31-norcycloartenol } \\
\text { (mixture of epimers }\end{array}$ & $\begin{array}{l}\text { Intermediate in the biosynthesis of } \\
\text { phytosterols }\end{array}$ & $\begin{array}{l}\text { Nyemba et al. } \\
\text { (1990) } \\
\text { Etounou (1991) }\end{array}$ \\
\hline $\begin{array}{l}\text { Bark, leaves, } \\
\text { seeds }\end{array}$ & $\begin{array}{l}\text { Cycloartane derivatives and triterpene } \\
\text { pentacycliane }\end{array}$ & Anti-inflammatory; anti-acids; antibacterial & IMPM (1987) \\
\hline Seeds & & Inhibitory effect on curare & $\begin{array}{l}\text { Kamanyi et al. } \\
(1990)\end{array}$ \\
\hline $\begin{array}{l}\text { Bark, seeds, } \\
\text { roots }\end{array}$ & $\begin{array}{l}\text { Dihydrochelerithrine, } \\
\text { 6-ac'etonyldihydrochelerithrine, and } \\
\text { lucidamine } \\
\text { [24] }\end{array}$ & $\begin{array}{l}\text { Antimicrobial, } \beta \text {-lactamase inhibitor; } \\
\text { cytotoxicity of fruits crude methanol extract; } \\
\text { weak activity on leukemia CCRF-CEM and } \\
\text { CEM/ADR5000 cells; pancreatic MiaPaCa- } \\
2 \text { cell lines }\end{array}$ & $\begin{array}{l}\text { Fotié et al. } \\
(2007) \\
\text { Gangou'e- } \\
\text { Pi'eboji (2007) } \\
\text { Kuete et al. } \\
\text { (2011) }\end{array}$ \\
\hline $\begin{array}{l}\text { Seeds and } \\
\text { stembark }\end{array}$ & & $\begin{array}{l}\text { Broad spectrum activity against all tested } \\
\text { Gram-negative bacilli; Good activity on non- } \\
\text { fermenter Gram-negative bacilli; High } \\
\text { potency on beta-lactam-resistant }\end{array}$ & $\begin{array}{l}\text { Gangoué-Piéboji } \\
\text { et al. (2009) }\end{array}$ \\
\hline Stem bark & $\begin{array}{l}\text { Putranjivic acid 1, methyl putranjivate } \\
3 \text {, their intermediary lactone } 2 \text {, }\end{array}$ & $\begin{array}{l}\text { Antimicrobial activity with good inhibitory } \\
\text { potential against Escherichia coli, }\end{array}$ & $\begin{array}{l}\text { Momo et al. } \\
(2011)\end{array}$ \\
\hline
\end{tabular}


Guedje et al., J. Appl. Biosci. 2017 Garcinia lucida Vesque (Clusiaceae): from traditional uses to pharmacopeic monograph for an emerging local plant-based drug development

\begin{tabular}{|c|c|c|c|}
\hline & $\begin{array}{l}\text { friedeline } 4 \text {, cycloartenol } 5, \\
1,2 \text {-dihydroxy- xanthone } 6, \\
1 \text {-hydroxy-2-methoxyxanthone } 7, \\
\text { betulinic acid } 8 \text {, oleanolic acid } 9, \\
\beta \text {-sitosterol } 10 \text { and stigmasterol } 11\end{array}$ & $\begin{array}{l}\text { Pseudomonas aeruginosa and Candida } \\
\text { albicans }\end{array}$ & \\
\hline Seeds & $\begin{array}{l}\text { Alkaloids, Flavonoids, Phenols, } \\
\text { Tannins, Anthraquinones }\end{array}$ & $\begin{array}{l}\text { Antibacterial activities alone and in } \\
\text { combination with PA } \beta N \text { on a panel of } \\
\text { Gram-negative bacteria }\end{array}$ & $\begin{array}{l}\text { Lacmata et al. } \\
(2012)\end{array}$ \\
\hline Bark, fruits & $\begin{array}{l}\text { Polyphenols, Steroids, Saponins, } \\
\text { Tannin, Flavonoids, Alkaloids, } \\
\text { Glycosides }\end{array}$ & $\begin{array}{l}\text { High Antiradical activity of the extract; nitric } \\
\text { and hydroxyl radical scavenging activity; } \\
\text { potent nitric oxide scavenging activity; } \\
\text { management of diseases in which radical } \\
\text { nitrite is directly involved; antioxidant } \\
\text { activity; cytotoxicity activity, antimicrobial } \\
\text { property and inhibitory effect of } \beta \text {-lactamase }\end{array}$ & $\begin{array}{l}\text { Djacbou et al. } \\
\text { (2014) }\end{array}$ \\
\hline
\end{tabular}

